\title{
A Descriptive Analysis on Effect of Corporate Governance on Investor's Decision
}

\author{
Dsouza Prima Frederick \\ Research Scholar, College of Management \& Commerce, Srinivas University, Mangalore- \\ 575001, India \\ OrcidID: 0000-0003-2568-5619; E-mail: primadsouza.cmc@ srinivasuniversity.edu.in
}

Area/Section: Business Management.

Type of the Paper: Review Paper.

Type of Review: Peer Reviewed as per $|\mathrm{C}| \mathrm{O}|\mathrm{P}| \mathrm{E} \mid$ guidance.

Indexed in: OpenAIRE.

DOI: https://doi.org/10.5281/zenodo. 5842836

Google Scholar Citation: IJMTS

\section{How to Cite this Paper:}

Dsouza, Prima Frederick., (2022). A Descriptive Analysis on Effect of Corporate Governance on Investor's Decision. International Journal of Management, Technology, and Social Sciences (IJMTS), 7(1), 1-10. DOI: https://doi.org/10.5281/zenodo.5842836

International Journal of Management, Technology, and Social Sciences (IJMTS) A Refereed International Journal of Srinivas University, India.

CrossRef DOI: https://doi.org/10.47992/IJMTS.2581.6012.0173

(C) With Author.

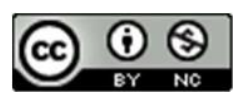

This work is licensed under a Creative Commons Attribution-Non-Commercial 4.0 International License subject to proper citation to the publication source of the work.

Disclaimer: The scholarly papers as reviewed and published by the Srinivas Publications (S.P.), India are the views and opinions of their respective authors and are not the views or opinions of the SP. The SP disclaims of any harm or loss caused due to the published content to any party. 


\title{
A Descriptive Analysis on Effect of Corporate Governance on Investor's Decision
}

\author{
Dsouza Prima Frederick \\ Research Scholar, College of Management \& Commerce, Srinivas University, Mangalore- \\ 575001, India \\ OrcidID: 0000-0003-2568-5619; E-mail: primadsouza.cmc@ srinivasuniversity.edu.in
}

\begin{abstract}
Purpose: The article studies the impact of internal factors and external factors influencing an investor's investment decision.

Design/Methodology: The information for the study was obtained from secondary sources like journal papers, magazines and books.

Findings: Human psychology has an internal role in investing choice, whereas corporate governance is an external influence. Corporate governance plays a major role in the investment decision-making process by revealing all elements of business information, but investors understand the information according to their own assessments and assumptions based on their psychology. As a result, a firm's transparency hardly impacts in investment decisions, and it only works to a limited extent; the rest of the investment selection process is dominated by human behaviour. However, the firm is transparent, there is no guarantee that the investor will always act rationally when making a choice for investment.

Originality/Value: Every investor should make rational decisions about their investments. Therefore, it is an investor's responsibility to follow the information provided by the firm, although some investors fail to do so. As a result of investor psychology, investors' investment decisions are beyond the reach of business transparency. The study implies that a behavioural survey will be useful in determining the factor influencing investors' investing decisions.
\end{abstract}

Type of Paper: Conceptual Paper

Keywords- Behavioural Finance, Corporate Governance, Psychology of an investor, Investment Decision.

\section{INTRODUCTION :}

In a rapidly changing market environment, making an investment decision is not easy. Every investor puts forth the greatest effort in building an investment considering the essential factors like regular timely returns, appreciation of capital funds, ensuring the principles of liquidity, solvency, and with rebates towards tax payments [1]. The investor relies on information obtained from government reports or secondary markets, corporate reports, consultants, relatives and friends, the newspaper, as well as one's own predictions and judgments [2]. Effective corporate governance is a fundamental area of research in finance that focusses on the domain of corporate governance. Corporate governance is one of the most frequently discussed topics in the business and in the field of finance. Almost all of the fastest growing economies are attempting to define and enforce sound corporate governance principles. Corporates following the principles of good governance attracts the potential investors.

\section{RELATED WORKS :}

The Indian economy has progressed from a planned economy to a market-driven one. The notion of corporate governance is becoming increasingly important in today's dynamic business environment. Few scholars have contributed their understanding towards corporate governance is exhibited below in Table 1. 
Table 1: Exhibits the contribution by different authors in corporate governance and investment decision.

\begin{tabular}{|c|c|c|}
\hline $\begin{array}{l}\text { Sr. } \\
\text { No. }\end{array}$ & Contribution & Reference \\
\hline 1. & $\begin{array}{l}\text { Investment decisions are the result of knowledge, expectation, and appraisal, } \\
\text { all of which are interconnected. Investors evaluate these elements on a regular } \\
\text { basis in order to make informed investment decisions. The element information } \\
\text { of investments or the facts includes both specific and general facts about the } \\
\text { portfolio of company. The investors may analyse data to make better investing } \\
\text { decisions. The second aspect, expectation, is linked to market knowledge } \\
\text { regarding investment alternatives, but it also includes financial and } \\
\text { environmental data. The size, regulation, earnings, safety, and negotiability of } \\
\text { certain assets are all considered in the valuation criteria. }\end{array}$ & [1] \\
\hline 2. & $\begin{array}{l}\text { The term corporate governance means collection of rules, procedures, and } \\
\text { practises that are used to guide and regulate the activities of a company. } \\
\text { Corporate governance primary responsibility is to strike a balance between the } \\
\text { interests of the company and the diverse stakeholders. Sound corporate } \\
\text { governance aids in the upkeep of the company's reputation. Transparency, } \\
\text { accountability, and security are the principles of corporate governance, which } \\
\text { contribute in the smooth operation of the firm and the formation of strong } \\
\text { professional relationships among the organization's stakeholders. }\end{array}$ & [3] \\
\hline 3. & $\begin{array}{l}\text { The most key qualities for corporate governance are maintaining the integrity } \\
\text { of accounting statements, few or no possibilities of embezzlement (ethical } \\
\text { behaviour), maximising shareholder value as the third most important } \\
\text { peculiarity, sound risk management practises, and safeguarding stock holders' } \\
\text { interests. }\end{array}$ & [4] \\
\hline 4. & $\begin{array}{l}\text { Individual investor behaviour is predicted with the study of two theories } \\
\text { namely, Theory of Reasoned Action (TRA) and Theory of Planned Behaviour } \\
\text { (TPB), as well as the impact of societal elements such as socialisation, media, } \\
\text { and the internet influence on investment decisions. The study indicated a strong } \\
\text { correlation between social contacts and media and individuals' trading } \\
\text { attitudes, but the internet had no impact on investment activity. The } \\
\text { significantly positive correlation established between trading desire and } \\
\text { trading behaviour. Investors' trading behaviour is heavily impacted by social } \\
\text { engagement and the media. }\end{array}$ & [5] \\
\hline 5. & $\begin{array}{l}\text { Descriptive research with a survey of } 100 \text { Indian investors was performed. The } \\
\text { survey noted that the majority of investors spend their own money in gold and } \\
\text { property because they provide a higher income in returns and the study also } \\
\text { revealed that education investors with high income level would prefer to invest } \\
\text { in zero risk alternatives and women investors who are known to be good } \\
\text { decision maker prefer investments promising higher returns with very low risk } \\
\text { profile. }\end{array}$ & [6] \\
\hline 6. & $\begin{array}{l}\text { Research looked into the investment habits of Nagpur households in the mid } \\
\text { income bracket. The researcher conducted this study to clarify a few key } \\
\text { concerns, such as middle-class households' financial plans and if there has } \\
\text { been an increase in family savings in Nagpur. The survey revealed that middle- } \\
\text { class households have a strong saving habit, but they do not want to save for } \\
\text { the foreseeable future, thus the government should take the required efforts to } \\
\text { raise education about investing money for the long haul }\end{array}$ & [7] \\
\hline 7. & $\begin{array}{l}\text { Many Indian investors are afraid to accept risks and prefer only government } \\
\text { initiatives. By encouraging investment activity, the investors can be the } \\
\text { backbone of economic progress. Behavioural finance will assist in the } \\
\text { discovery of unresolved issues regarding the stock market, as well as teaching } \\
\text { investors how to make stock market investment decisions that will help the } \\
\text { Indian economy grow. Therefore, domestic investors may avoid common }\end{array}$ & {$[8][14]$} \\
\hline
\end{tabular}


investment blunders and employ financial market tactics to achieve a high rate of return

\section{RESEARCH GAP :}

Corporate scandals in recent decades, some of which are still ongoing, have featured a high frequency of inappropriate acts by management dispossessing a firm's resources at the expense of stakeholders. The Satyam case in India illustrates very well how company leaders, financial authorities, and internationally famous auditors may exploit the system. This not only decimates the company's wealth and those of its stakeholders, but it also undermines a country's economy and credibility. Moreover, the strong company governance failure scams, namely the stock market scam, the Ketan Parikh scam, the Satyam scam and the UTI scam, which created a notable remark and fear among investors, created a need for development of good corporate governance in India which can have a significant impact on the country's development. After witnessing this awful scenario in the corporate sector, governance has become a need not only for efficient business but also to satisfy the various economic interests and improved organizational quality. As a result, corporate governance has become a hot topic of discussion, as well as a standard regulatory and academic abbreviation. Therefore, there is a need to study the relevance and its effect on investors investment decision.

\section{RESEARCH AGENDA :}

The study has following agenda:

1. What is the role of corporate governance on investment decision?

2. Is there any impact of corporate governance on investors decision?

3. Is investment decision affected due to human psychology?

4. What are the strengths, weakness, opportunities and challenges of corporate governance?

5. What are the suggestions for improvement in the corporate governance?

\section{OBJECTIVES OF THE STUDY :}

1. To understand the role of corporate governance on investment decision.

2. To analyse the implication of corporate's governance on investors' decision.

3. To identify the human psychological factors affecting the investment decision.

4. To analyse the corporate governance by use of SWOC analysis.

5. To give suggestions for improvement based on findings.

\section{METHODOLOGY :}

The nature of the paper is conceptual and descriptive. The research study relied on secondary information. This article's sources of information include research publications, journals, magazines and books. SWOC analysis were used to analyse the corporate governance and investment decision.

\section{CORPORATE GOVERNANCE ON INVESTMENT DECISION :}

Investors are highly interested in the financial accounts of a firm before making an investment choice. For their investment choice, every investor conduct a thorough examination of the company's overall data. By providing complete information about a firm, corporate governance plays a vital part in an investment choice. Transparency, accountability, and security enhance corporate governance, all of which are critical to any business [17]. Each of the cornerstones has played an important role in the firm. The company's transparency in corporate governance disclosures allows outsiders to have clear watch over the operations and transactions [15]. When anything goes wrong, the company's accountability discloses the company's disclosure and transparency or liability. The company's security shows how the company protects the sensitive data from unwanted access. Therefore, these principles when followed strictly the company impacts ones' mindset to make investment decision.

\section{IMPLICATION OF CORPORATE GOVERNANCE ON INVESTORS' DECISION :}

The company's integrity is a critical factor for investors when making investment decisions. The company's transparency includes reporting of financial data and non-financial information. It implies that a particular has obliged to all legal requirements. Therefore, all the organisation should disclose relevant information about the company's overall operations to the interested stakeholders. The company's openness contributes to the company's positive market reputation. It gives comprehensive 
information about the firm, making it a valuable resource for investors seeking to make an investment choice in a specific company. The investor examines the firm's financial and other characteristics in order to make an investment choice in that company. Therefore, corporate governance is an important factor to consider while making an investment choice. Although information is vital to investors, corporate governance aids them in making decisions by providing corporate information [4]. Internal and external factors impact an investor's informed investment decision. Human psychology has an inherent role in the investing choice, whereas corporate governance is an external influence. Investors have been known to make investment decisions based on information obtained from the financial or capital markets, corporate reports, consultants, friends and relatives, the information providers, and their own presumptions [12].

Corporate governance is vital in the investment decision-making process since it publishes firm information in all facets, but investors interpret information based on their own opinions and beliefs. As a result, a new discipline is needed to comprehend human psychology in financial decisions [8][9].

\section{HUMAN PSCHYLOGICAL FACTORS INFLUENCING INVESTMENT DECISION :}

Several behavioural biases affect investors, resulting in psychological mistakes and poor decisionmaking. When faced with difficult and confusing judgments, investors use basic guidelines to make likely, inefficient conclusions. Theoretically, behavioural biases are described in the same manner as formalised errors in judgement formation occur. Over time, researchers compiled an extensive list of apparent biases, which they then applied to individual investor behaviour to see how it affected their judgments. Although this description of bias is helpful, no basic explanation regarding why investors are prone to certain biases has been established. The following behavioural biases are taken into account in this study:

\subsection{Overconfidence}

It is lack of confidence in one's own expertise, cognitive thinking, and decisions. Overconfidence causes investors to inflate their expertise, undervalue risks, and overestimate their capacity to control events. Moreover, investors assume they are more intelligent and have superior knowledge than they actually do. Same applies to the stock market, whether it comes to picking stocks and deciding when to enter or quit a position, investors tend to be overconfident in their own judgement. Overconfident investors engage in excessive trading, resulting in low returns and a failure to diversify their portfolio correctly.

\subsection{Representativeness}

It is also known as small sample neglect, and it is the estimation of future occurrences based on a restricted set of information or facts. Additionally, representativeness bias is a conclusion based on an over-reliance on previous performance, with investors believing that the current trend will continue for the foreseeable future. This bias has a number of implications for financial decision-making. In financial markets, lack of representativeness leads to bad decision-making.

\subsection{Herd Behaviour}

In financial markets, collaborative emulation may be described as the merging of several investors' activities. This is the most common blunder, in which investors follow the majority's investing selections. That is why, in the stock market, when an investor believes that now is the optimum moment to purchase or sell a position and that he should move quickly, he is met with significant peer and psychological pressure to refrain.

\subsection{Anchoring}

It is the proclivity to tie or anchor one's thoughts to a reference point, even if that reference point is irrelevant to the current choice. In the stock market, for example, certain investors are more likely to buy a stock that has dropped dramatically from its recent peak. They are anchored on the stock's recent highs and believe that the current low price represents a strong investing opportunity.

\subsection{Cognitive Dissonance}

It is the psychological struggle that investors encounter when they are confronted with evidence that their assumptions and expectations were incorrect. Furthermore, when an investor is faced with a circumstance in which he must choose between two options, it is likely that some disagreement will follow once a selection has been made. The downsides of the option they choose are likely to be more evident, while the advantages of the overlooked choice will fuel the struggle. This will cause the investor's faith in his investment decision to be questioned. 


\subsection{Regret Aversion}

When investors fail to make a choice because they are afraid of the outcome, they are prone to regret aversion bias. It aims to explain why investors refuse to admit that they made a bad investment decision to themselves. Investors who are susceptible to this bias are hesitant to sell assets in which they have made losses to avoid in future the regret of making again the mistake if taking ineffective and poor decision. The tendency of investors to detest recognising their mistakes is the source of regret aversion. Furthermore, investors may avoid making investing decisions as a result of this bias, fearing that whatever decision they make would be illogical.

\subsection{Loss Aversion}

Investors have a predisposition to avoid losses even when there are likely to be returns. As a result, investors typically cling onto losing equities for longer than they should since selling them will result in a loss; yet, it will just be a paper loss. Loss Aversion is linked to money's marginal utility, where the first rupee is valued more highly than subsequent rupees. Loss aversion is an unavoidable phenomenon in which investors react negatively to losses rather than positively to profits.

\section{SWOC ANALYSIS OF CORPORATE GOVERNANCE :}

Corporate governance is a set of policies, processes, and regulations that govern, regulate, and administer businesses. The phrase refers to both internal and external aspects that affect the interests of a company and its shareholders, such as investors, customers, vendors, government entities, and management. The SWOC (Strength's, Weakness, Opportunities and Challenges) analysis [19] of corporate governance is given below:

\subsection{Strength :}

Good corporate governance is essential to a company's continued survival. This is nothing more than the manner in which an organisation is managed or governed. By assuring the company's commitment to increased growth and earnings, good governance encourages and enhances investor trust. The necessity for the expansion of the corporate governance concept is naturally and primarily concerned with achieving 'corporate governance objectives.' The purpose of the corporate governance system is to achieve the following objectives:

1. Investment returns and socioeconomic development are ensured by good company governance.

2. Sound corporate governance maintains investor trust, allowing a company to quickly raise public offerings and capital.

3. The market prices of the stock will have a favorable impact with good value.

4. It offers proprietors and management a good chance to achieve their objectives in the best interests of shareholders and the company.

5. Fraud, corruption, risk, and misfeasance are all reduced by good company governance.

6. It contributes in the innovation and implementation of brands.

7. It ensures that the organisation is administered in the best interest of the stakeholders.

\subsection{Weakness :}

Corporate governance is complicated and often challenging, and it is only becoming more complicated as the world goes forward and changes at a faster pace. It's weakness are as follows:

1. Authorities and administrators in charge of a corporation's internal affairs and the majority of its policies are often not stakeholders. This might be a concern for publicly traded corporations. The assets of the firm will be administered by the management board and officials if there is no shareholder and the majority of shareholder in annual general meeting will vote by proxy. The separation between ownership and management will cause a rift of interest between management's mandate to maximise shareholder value and boost revenue.

2. Corporate leaders, managers, and workers are referred to as corporate insiders because they may have access confidential information might increase the viability of their stock. Insiders are not prohibited from trading in corporate securities, but they must report their transactions to the Securities and Exchange Board of India (SEBI).

3. Illegal Insider trading takes place when a shareholder sells a stock without having any factual information but knows the confidential information which can increase his share value. Therefore, illegal insider trading operates more in present days. A government official, an independent auditor, or a family member of the company who is not directly involved with the firm may potentially engage in 
illegal insider trading. Because secret company information is freely available, enforcing anti-insider trading regulations can be challenging.

4. There are several strategies to deceive investors by presenting factually accurate financial figures in a misleading manner.

5. Because of the misuse of corporate governance, a greater variety of legal frameworks have been enacted to prevent future abuses. Companies may find it difficult and costly to comply with this regulation.

\subsection{Opportunities :}

The board of directors is in charge of the corporation's long-term viability. This is not a task that can be delegated to management. The following is a summary of the value addition that corporations are expected to obtain through fair and successful corporate governance practises:

1. The implementation of effective governance mechanisms provides the organisation with sustained growth.

2. A robust governance system, as evidenced by the implementation of excellent corporate governance standards, instils trust in current and potential stakeholders.

3. Investors are prepared to pay a higher premium for a company that demonstrates rigorous compliance to internationally recognised corporate governance standards.

4. Appropriate governance lowers anticipated risks, which lowers the cost of borrowing; it also allows the higher authorities to make better decision which favours the company's prospects.

5. Directors with expertise skill and knowledge enjoy the benefits of leveraging the market edge.

6. Good corporate governance creates a healthy relationship with the stakeholders in long run [20].

7. The company and people associated can have prestigious image and enjoys a high level of esteem.

8. Potential stakeholders would like to support businesses that have outstanding governance.

\subsection{Challenges :}

There are numerous conceptual hurdles that firms face when it comes to corporate governance. There are a handful that are very important and have a significant impact on the organization's governance process.

1. Separating the Board and Management Roles.

2. Choosing the appropriate members of the Board of Directors.

3. Differentiate the CEO and Chairperson's Roles.

4. Board of Directors re-election.

5. Measuring the compensation of Directors and Management

6. Policies for shareholder Rights Safeguards.

7. The company's social responsibility towards different stakeholders.

\section{FINDINGS :}

The key findings of this research are as follows.

1. Indian civilizations are not unfamiliar with corporate governance norms.

2. Not all nations have the same corporate governance principles and ideas.

3. Corporate governance concept plays a vital in company's fair operation therefore, its concepts are widely discussed in the business and financial world.

4. A corporation without a corporate governance framework is sometimes compared to a body deprived of a lively soul

5. A favourable corporate governance practice followed by company picture enhances the business image.

6. Satyam Computer Services Limited, India's was the most remembered case of corporate fraud and governance disaster, was discovered at a time when concerns about strong corporate governance were at an all-time high.

7. It also serves a variety of corporate interests and brings quality management to the platform, which optimises shareholders' wealth and has can favourably influence the growth and stability of economy as whole.

8. Corporate governance principles, norms and practices are widely accepted across several nations, with help from governments and international organisations. They were mostly published by stock exchanges, corporations, investment firms, or organizations, academies of directors and managers. 
Inadequate and lacking corporate governance principles in firms may result in monetary losses, malfeasance, and a degraded image, which can damage a country's overall economy and prestige.

9. Shareholders may withdraw due to fear, distrust, and contempt as a result of dishonest and unethical transactions. As a result, businesses must conform to and observe the rules. In every endeavour, honesty is the best policy. Corporate scandals, fraud, and civil and criminal responsibility may all be avoided with good corporate governance, and it improves a public reputation in the public's eyes.

\section{SUGGESTIONS :}

Good regulations, like good boundaries, help societies to be well-ordered. User will have an ordered corporation if your rules are very well, transparent, reasonable, and most importantly, observed.

1. Board members must have full-fledged knowledge and information and emphasize on following ethical practice diligently for company's and shareholders' best interests.

2. Examine and direct business strategy, goal-setting, major action plans, risk policies, financial plans, and yearly budgets.

3. Get into charge of big purchases and dispositions.

4. Oversee long term planning and choose, compensate, supervise, and replace key executives.

5. Integrate significant executive and board salaries or compensation packages with the company's and its shareholders' long-term objectives.

6. Follow a comprehensive and open nomination and selection procedure for board members.

7. Ensure the accounting and financial reporting processes of the company are accurate, including an external inquiry.

8. Confirm certain efficient internal control measures are in place.

9. Oversee the transparency and communication process.

10. Whenever board committees are formed, its mission, members, and operating practices should be clearly defined and made public.

\section{SUMMARY AND CONCLUSION :}

Internal and external variables influence the investor's investing decision. Corporate governance plays an important part in investing decisions by providing comprehensive corporate information, but investors interpret the information based on their own assumptions and opinions [10]. In a nutshell, business corporate governance plays less influence on the investment decision but the human behaviour affects more in investment selection and decision [16]. Even if the firm is transparent, there is no guarantee that the investor will always act rationally when making an investment choice. Every investor should make reasonable decisions about their investments.

It is an investor's responsibility to follow the information provided by the firm, although some investors fail to do so [18]. Moreover, investors' investment decisions are made outside the scope of company transparency because factors such as extreme loyalty to government initiatives, a lack of financial learning, ethnic barriers, inadequate judicial systems policing, lax accounting reporting standards, and information disclosure lead investors to act on impulse rather than sensibly [8][11][13][21]. In addition, investors' investment decisions are beyond the realm of business transparency. Therefore, the study implies that behavioural research will be useful in determining the factor influencing investors' decisions on investment.

\section{REFERENCE :}

[1] Bhalla, V. K. (2006). Fundamentals of Investment Management. S. Chand Publishing. pp 115. Google Scholar $X^{7}$

[2] Social Factors Influencing a Financial Decision, https://smallbusiness.chron.com/social-factorsinfluencing-financial-decision-81620.html retrieved on 19-11-2021

[3] Roman, Alexandrea. The Three Pillars of the Corporate Governance. January 30, 2014, updated October 24, 2017. https://www.azeusconvene.com/three-pillars-of-corporate-governance/. Retrieved on 20-11-2021.

[4] Noronha, M. R. and Mehta, P. U. (2012). Corporate Governance and Investment Decisions. Prabandhan: Indian Journal of Management, 5(5), 41-46.

Google Scholar $\chi^{\top}$ 
[5] Shanmugham, R. and K. Ramya (2012). Impact of Social Factors on Individual Investors' Trading behaviour. Economics and Finance (Elsevier), 2(1), 237-246.

Google Scholar $X^{\nearrow}$

[6] Murithi, S. Suriya, B. Narayanan, and M. Arivazhagan. (2012). Investors Behaviour in Various Investment Avenues - A Study. International Journal of Marketing and Technology, 2(7), 164189.

Google Scholar $x^{7}$

[7] Samudra, Aparna and M. A. Burghate (2012). A Study on Investment Behaviour of Middle-Class Households in Nagpur. International Journal of Social Sciences and Interdisciplinary Research, 1 (5), 43-54.

Google Scholar $X^{\nearrow}$

[8] Agarwal, A., Verma, A., \& Agarwal, R. K. (2016). Factors influencing the individual investor decision making behavior in India. Journal of Applied Management and Investments, 5(4), 211222.

Google Scholar X

[9] Pompian, Michael M. Behavioural Finance and Wealth Management: How to Build Optimal Portfolios That Account for Investor Biases. John Wiley \& Sons, Inc, Canada, 2006.

Google Scholar $X^{\top}$

[10] Li, Hua, Li-na Zhao, and Qiu-bai Sun (2014). Nonlinear Analysis and Empirical Test of the Investor Sentiment Index System based on OLS and the DSSW model. Bio Technology an Indian Journal (BTAIJ), 10(20), 11915-11921.

Google Scholar $X^{\top}$

[11] Shanmugasundaram, V., and Jansirani, N. (2012). P. Sathish Chandra Influential Factors in Investment Decision Making. South Asian Journal of Marketing \& Management Research, 2(6), 96-106.

Google Scholar $\chi^{7}$

[12] Popescu, G. H. (2012). Corporate governance and managerial cognition. Economics, Management, and Financial Markets, 7(4), 245-250.

Google Scholar $X^{\top}$

[13] Enskog, Dorothee. How Culture Impacts Investment Behaviour. 2015, https://www.creditsuisse.com/corporate/en/articles/news-and-expertise/how-culture-impacts-investment-behavior201502.html. Retrieved on 21-11-2021.

[14] Fisher, Kenneth L., and Meir Statman (2000). Investor Sentiment and Stock Returns. Financial Analysts Journal (CFA Institute), 56(2), 16-23.

Google Scholar ${ }^{7}$

[15] Grinblatt, Mark and Matti Keloharju (2009). Sensation Seeking, Overconfidence, and Trading Activity. The Journal of Finance, 64(2), 549-578.

Google Scholar $\chi^{\top}$

[16] Langer, Ellen Jane (1975). The Illusion of Control. Journal of Personality and Social Psychology, 32(2), 311-328.

Google Scholar $X^{\top}$

[17] Ritter, Jay R. (2003). Behavioural Finance. Pacific-Basin Finance Journal, 11(4), 429-437. Google Scholar $X^{\top}$

[18] Sultana, Syed Tabassum (2010). An Empirical Study of Indian Individual Investors' Behaviour. Global Journal of Finance and Management (Research India Publications), 2(1), 19-33.

Google Scholar $x^{7}$

[19] Aithal, P. S. (2017). Industry Analysis-The First Step in Business Management Scholarly Research. International Journal of Case Studies in Business, IT and Education (IJCSBE), 1(1), 113. 
Google Scholar $\chi^{7}$

[20] John, K., \& Senbet, L. W. (1998). Corporate governance and board effectiveness. Journal of banking \& Finance, 22(4), 371-403.

Google Scholar $X^{\top}$

[21] Shleifer, A., \& Vishny, R. W. (1997). A survey of corporate governance. The journal of finance, 52(2), 737-783.

Google Scholar $x^{7}$

$* * * * * * * * * * * * *$ 